\title{
Documenting 6,000 Years of Indigenous Fisheries and Settlement as Seen through Vibracore Sampling on the Central Coast of British Columbia, Canada
}

\author{
Seonaid Duffield (D), Jennifer Walkus, Elroy White, Iain McKechnie (D), Quentin Mackie, \\ and Duncan McLaren
}

This article highlights the utility of vibracore technology to sample deep shell midden deposits on the Central Pacific Coast of British Columbia, Canada. Analysis of six core samples and 21 radiocarbon dates revealed that the archaeological deposits extended to a depth of $544 \mathrm{~cm}$ below surface and that occupation began approximately 6,000 years ago, continuing into the sixteenth century AD. Zooarchaeological identification of fine screened $(2 \mathrm{~mm})$ sediments shows that fish constitute $99.8 \%$ of identified vertebrate fauna, with a focus on herring (Clupea pallasii), salmon (Oncorhynchus sp.), rockfish (Sebastes sp.), and greenling (Hexagrammos sp.), followed by a variety of other fish taxa utilized throughout the occupation of this site. Despite a much smaller examined volume relative to conventional excavation, vibracoring was effective in recovering deep, stratigraphically intact, and adequate samples of zooarchaeological fisheries data as well as a considerable number of stone, bone, and shell artifacts (an estimated 550 artifacts per cubic meter of cultural sediments). These results show a persistent and sustainable ancient fishery through six millennia until the contact period. The field and laboratory methods described are especially conducive to sampling large and deep shell midden deposits repetitively.

Keywords: Northwest Coast, Central Coast, British Columbia, Canada, zooarchaeology, core sampling, vibracore, shell midden, fauna, artifacts

El presente artículo destaca la utilidad en la aplicación de la tecnología "Vibracore" para muestrear un sitio de "Conchal o Conchero" en la Costa Central del Pacífico de la Columbia Británica, Canadá. El análisis de seis muestras claves y 21 muestras datación de radiocarbono reveló que la más temprana ocupación de este sitio arqueológico, a una profundidad de 544 cms desde la superficie se estableció aproximadamente 6,000 años atrás, continuando hasta el Siglo XVI a.n.e., durante el cual, el mismo fue repetidamente ocupado y en un proceso de acumulacion constante. Los sedimentos del conchero se procesaron a través de pantallas de $2 \mathrm{~mm}$ y revelaron arenque (Clupea pallasii), salmón (Oncorhynchus sp.), rockfish (Sebastes sp.) y greenling (Hexagrammos sp.) fueron capturados a través de la ocupación del sitio. A pesar de que el volumen examinado es mucho más pequẽ̃o, la metodología de extracción de muestras fue eficaz para recuperar una gran cantidad de artefactos pequeños líticos, huesos y conchas (aproximadamente 550 artefactos por metro cúbico de sedimentos culturales). Lo cual indica que los métodos de campo y de laboratorio utilizados, son especialmente propicios para la recuperación de pequeños artículos. Estos resultados muestran una pesquería local persistente y sostenible durante seis milenios hasta el período de contacto.

Palabras clave: Costa Noroeste, Costa Central, Columbia Británica, Canadá, aooarqueologia, muestra de núcleo, vibrosondeo, yacimiento de conchas, fauna, artefactos

\footnotetext{
Seonaid Duffield $\boldsymbol{\Xi}$ Independent Scholar, Victoria, British Columbia, Canada (seonaid.e.duffield@ gmail.com, corresponding author)

Jennifer Walkus - Wuikinuxv First Nation, Port Hardy, British Columbia, Canada (j_walkus@ @otmail.com)

Elroy White Central Coast Archaeology, Bella Bella, British Columbia, Canada (xanius_elroywhite@ hotmail.com) Iain McKechnie - Hakai Institute; Department of Anthropology, University of Victoria, Victoria, British Columbia, Canada (iim@uvic.ca)

Quentin Mackie Department of Anthropology, University of Victoria, Victoria, British Columbia, Canada (qxm@uvic.ca) Duncan McLaren — Hakai Institute, Victoria, British Columbia, Canada (duncan.mclaren@ hakai.org)
}

American Antiquity 87(1), 2022, pp. 168-183

Copyright (C) The Author(s), 2021. Published by Cambridge University Press on behalf of the

Society for American Archaeology. This is an Open Access article, distributed under the terms of the Creative Commons Attribution licence (http://creativecommons.org/licenses/by/4.0/), which permits unrestricted re-use, distribution, and reproduction in any medium, provided the original work is properly cited.

doi:10.1017/aaq.2021.113 
$\mathrm{A}$ rchaeologists on the Northwest Coast are perpetually confronted with the challenge of adequately sampling large shell midden sites because these deposits can be expansive and deep, and they can contain an overwhelming abundance of faunal remains. Conventional excavation is time consuming and faces logistical constraints, particularly where recorded deposits are commonly over $3 \mathrm{~m}$ deep and $5,000 \mathrm{~m}^{2}$ in extent (Cannon 2002, 2020; Letham 2014; McKechnie 2015). Archaeologists have employed a number of different sampling strategies in order to collect archaeological data, including core and auger sampling (Cannon 2000a; Casteel 1970; Letham et al. 2017, Martindale et al. 2009; Stein et al. 2003), and to investigate millennial-scale trends in subsistence patterns within coastal shell midden sites (Cannon 2000b; Cannon et al. 2011; Moss 2012).

This article reports on the use of a vibracore to obtain multiple chronologically overlapping samples from a single large and deep shell midden site (EjTa-13) to investigate Indigenous settlement and fisheries management on the Central Coast of British Columbia. The study site is situated on the west side of Hecate Island and is protected from the open ocean by Calvert Island to the west and south, and the relatively sheltered Fitz Hugh Sound to the north and east (Figure 1). Meay Channel (or Northern Kwakshua) and Kwakshua Channel separate Hecate and Calvert Islands.

The site of EjTa-13 is situated in a $230 \mathrm{~m}$ wide protected bay near the southwest corner of Hecate Island, facing Meay Channel. The site is covered by dense salal and stands of conifers, including western redcedar and coastal western hemlock. Hecate Island is in the central temperate rainforest of British Columbia, with cool summers and mild, very wet winters.

\section{Regional Archaeological Investigations and Zooarchaeological Sampling Approaches}

Survey and excavation projects on the Central Coast have occurred at a number of sites beginning in the 1940s (Carlson 1976; Conover 1972; Drucker 1943; Luebbers 1971; Pomeroy 1972). Namu (Mawas, ElSx-1) is the most intensely excavated and reported site, where a record of continuous human occupation spans 11,000 years BP (Cannon 1991, 1995; Hester and Nelson 1978; Pomeroy 1980). It includes temporal components (Periods 1-6) spanning the Holocene, including the early Holocene $(11,480-5760$ cal BP), but with faunal assemblages preserved in temporally distinct components (Periods 3-6) dating to within the past 6,000 years (Cannon 1991, 1996, 2000a).

Due to the large size and depth of many shell midden sites, it is uncommon for researchers on the Northwest Coast to excavate an entire shell midden site, let alone analyze the vast amount of preserved shell and bone (Gray 2008; Lyman 1991). As such, sampling is necessary, most commonly using column or auger sampling. Site impacts are much larger when excavation is undertaken than when most coring methods are used, and as a result, there is a higher chance of disturbing human burials, which occur in shell midden sites in the area. A challenge in core sampling is the small diameter of commonly used percussion coring devices $(<5 \mathrm{~cm})$. Although suitable for documenting stratigraphy and obtaining datable samples, it lacks adequate recovery of vertebrate fauna due to the very small volume recovered. Alternatively, bucket auger sampling has a larger diameter $(7-15 \mathrm{~cm})$. This recovers volumes sufficient for zooarchaeological analysis, but the twisting motion of the auger physically disturbs the sediment and constrains fine-scale vertical comparisons as well as fragments larger bones and shells (Cannon 2000b). Column sampling from the sidewalls or portions of a conventional excavation unit is another method for fine-screen recovery, but it is rarely conducted in multiple areas of a site (Cannon 2000b, 2013; Casteel 1976; Letham 2014; McKechnie 2005, 2012).

Pairing percussion coring and auger sampling using an Environmentalist's Subsoil Probe (ESP) and a bucket auger provides a quick, efficient, and cost-effective method to extract zooarchaeological and paleoenvironmental data from a variety of site areas; these methods also provide an alternative to large-scale excavation and are established methods on the Northwest Coast (Letham 2014; Martindale et al. 2009; McKechnie 2015; Taylor et al. 2011)—or more specifically, on the 


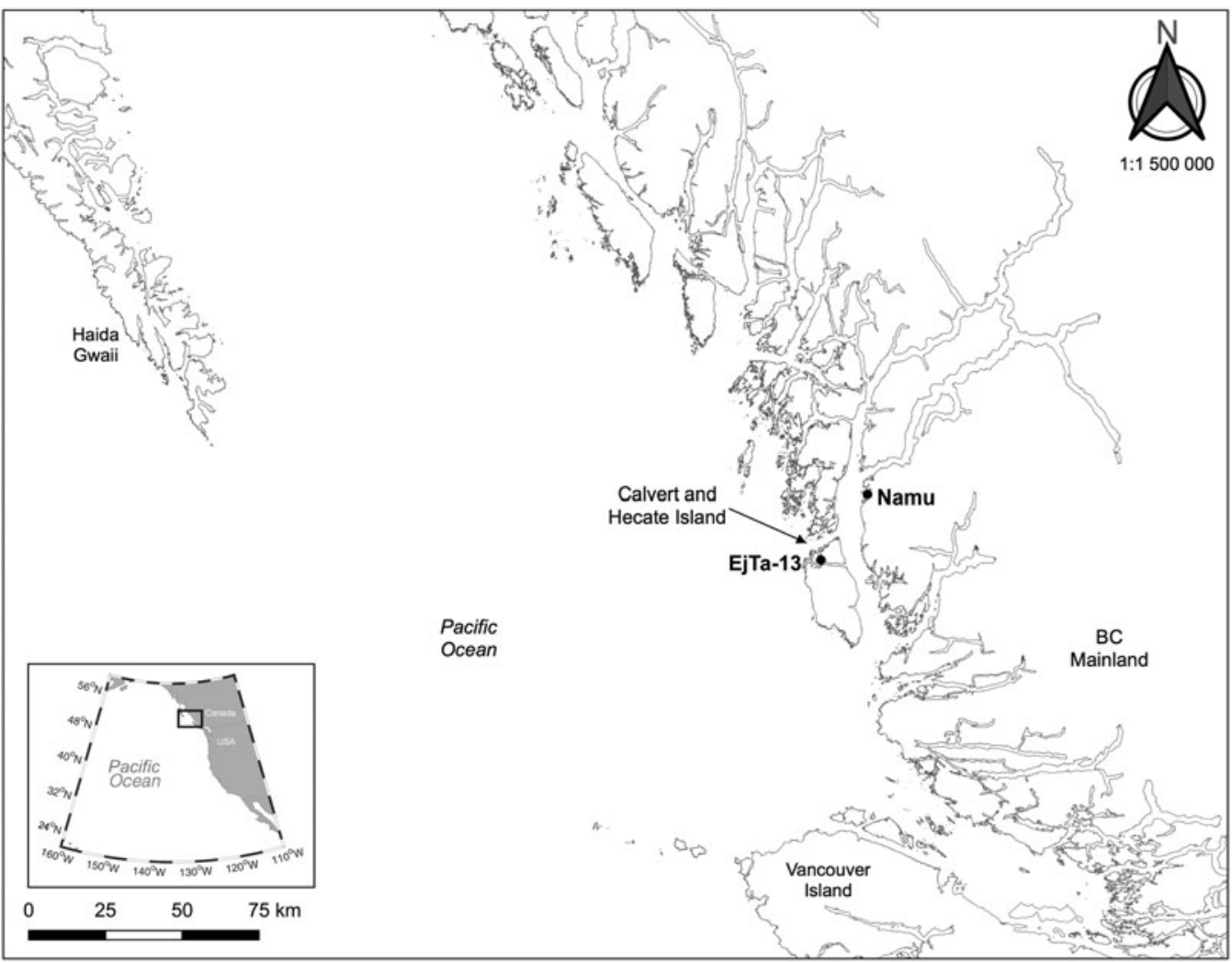

Figure 1. Overview map of the study location within British Columbia (created by Seonaid Duffield).

Central Coast (Cannon 2000a, 2000b, 2013; Cannon et al. 2011; McLaren 2013, 2014). However, a drawback of using this approach is that auger sampling churns the sediments, and the device must be removed in $10-20 \mathrm{~cm}$ increments, which can result in contamination. Percussion cores are not used for collecting a representative faunal sample, which is due, in part, to the small diameter cores recovering very small volumes of sediments. In contrast, bucket augers have effectively recovered fauna from deep shell midden deposits.

Collected in association with excavation units, column samples are comparable or larger in volume to an auger core sample test. Column samples are fixed volumes of archaeological matrix removed from a wall of an excavation unit to document the fine-scale contents of the sediments (e.g., fauna). This is facilitated by $100 \%$ examination of washed sediments in a well-lit laboratory environment (Casteel 1976).
Column sampling (as well as auger sampling) is an established method for investigating the most frequently occurring fauna in cultural sediments, which are typically fish and shellfish remains (Casteel 1976; Conover 1978; McKechnie 2005; Sumpter 2005), but it is less effective for recovering comparatively less abundant and larger faunal elements such as mammal and bird bones. Given that an excavation unit is required prior to sampling, the areal extent of column sampling is limited by the amount of excavation that occurs across the site.

\section{Methods}

\section{Field Methods}

Vibracoring is an efficient means of obtaining intact stratigraphic records and fauna within a vertical column of archaeological sediments. This coring device facilitates access to both radiocarbon date samples and fauna. In addition, 
vibracoring uses a wider diameter core than traditionally employed methods such as bucket auger and ESP core samples. We tested the vibracore device in a previously identified but uninvestigated shell midden site, EjTa-13, in Meay Channel on the eastern shoreline in a protected bay in proximity to the Hakai Institute's Calvert Island Ecological Observatory.

Vibracoring works on the principles of highfrequency ultrasonic vibrations: the drill head and drill rods are attached to a 6.5 horsepower engine, which transmits 7,000-12,000 acoustic vibrations per minute to the mechanical "flex cable," which is attached to the drill head (Figure 2A). ${ }^{1}$ Aided by gravity and highfrequency vibrations, the vibracore collects sediments into a $7.5 \mathrm{~cm}$ diameter plastic sample tube inserted within the drilling rod (each rod is a maximum of $152.5 \mathrm{~cm}$ in length; Figure 2B). A specially built drill bit was designed to push cobble-sized clasts out of the way. Once the proximal rod has been drilled to approximately $15 \mathrm{~cm}$ above ground surface, the drill string is hoisted out of the surrounding sediment using a winch system.

Using this method, we recovered seven successful core samples (VC1 through VC7; Figure $2 \mathrm{C}$ ) up to $5 \mathrm{~m}$ in length from the site, totaling approximately $100 \mathrm{~L}$ of cultural-bearing sediments. The cores were analyzed in a laboratory setting at the University of Victoria. Stratigraphy from cores was documented (Supplemental Figures 1-7), and charcoal samples were selected for radiocarbon dating with a focus on stratigraphic transitions and basal cultural deposits (Duffield 2017).

\section{Laboratory Methods}

To document stratigraphy across sections of individual core samples, we split cores in half lengthwise, photographed and recorded the stratigraphy, and then partitioned the core sample into $5 \mathrm{~cm}$ thick sections $(0.2 \mathrm{~L})$. To establish chronology, we submitted 21 radiocarbon dates on terrestrial charcoal to the Keck Carbon Cycle AMS facility at the University of California Irvine (UCIAMS). Calibrations were calculated with Calib 8.2 (Stuiver et al. 2021) using the IntCal20 curve (Reimer et al. 2020). Table 1 provides a complete summary of charcoal-derived radiocarbon ages from multiple vibracore tests (VC1, VC3-VC7). The first core was dated intensively, focusing on clear stratigraphic breaks, whereas charcoal was submitted from the earliest and latest cultural bearing sediments for core samples that followed. ${ }^{2}$ The VC1 core sample returned a continuous series of dates, ranging from 5000 to $1200 \mathrm{cal} \mathrm{BP}$, and reflected stratigraphic integrity except for one minor date reversal. Subsequent dating determined that the tested site area was occupied between 5800 and 380 cal BP.

Site stratigraphy was grouped into three major layer categories due to the inherent complexity exhibited in most Northwest Coast shell midden sites (Stein 1992; Stein et al. 2003) and included minerogenic, cultural, and organic layers. See Supplemental Text 1 for more information relating to site stratigraphy.

All subsamples were screened through $2 \mathrm{~mm}$ mesh (cf. Moss et al. 2017). We identified faunal remains using the extensive zooarchaeological comparative collection at the University of Victoria under the guidance of faunal identification specialist Rebecca Wigen (Pacific Identifications Inc.). Basic measures of abundance for vertebrate fauna were tallied, including the number of identified specimens (NISP) and number of (unidentified) specimens present (NSP). NISP is used to calculate relative abundance (i.e., the percentage of a particular item relative to all other specimens within the same category), per liter (i.e., it shows the number of specimens per liter of cored volume), and ubiquity (i.e., it refers to the percentage of contexts in which a certain taxon is present or absent).

\section{Results}

The total number of vertebrate specimens examined from the $2 \mathrm{~mm}$ fraction is 17,959 , which includes fish, mammal, and bird. Of the overall total, 6,417 specimens could be identified to family, genus, or species level, representing 23 fish taxa, nine mammals, and two birds across all seven core samples. Typical of many Northwest Coast shell midden sites, fish taxa are overwhelmingly the most numerically abundant class of vertebrate fauna recovered from the site.

Figure $3 \mathrm{~A}$ illustrates continuity of the four most ubiquitous and relatively abundant taxa 


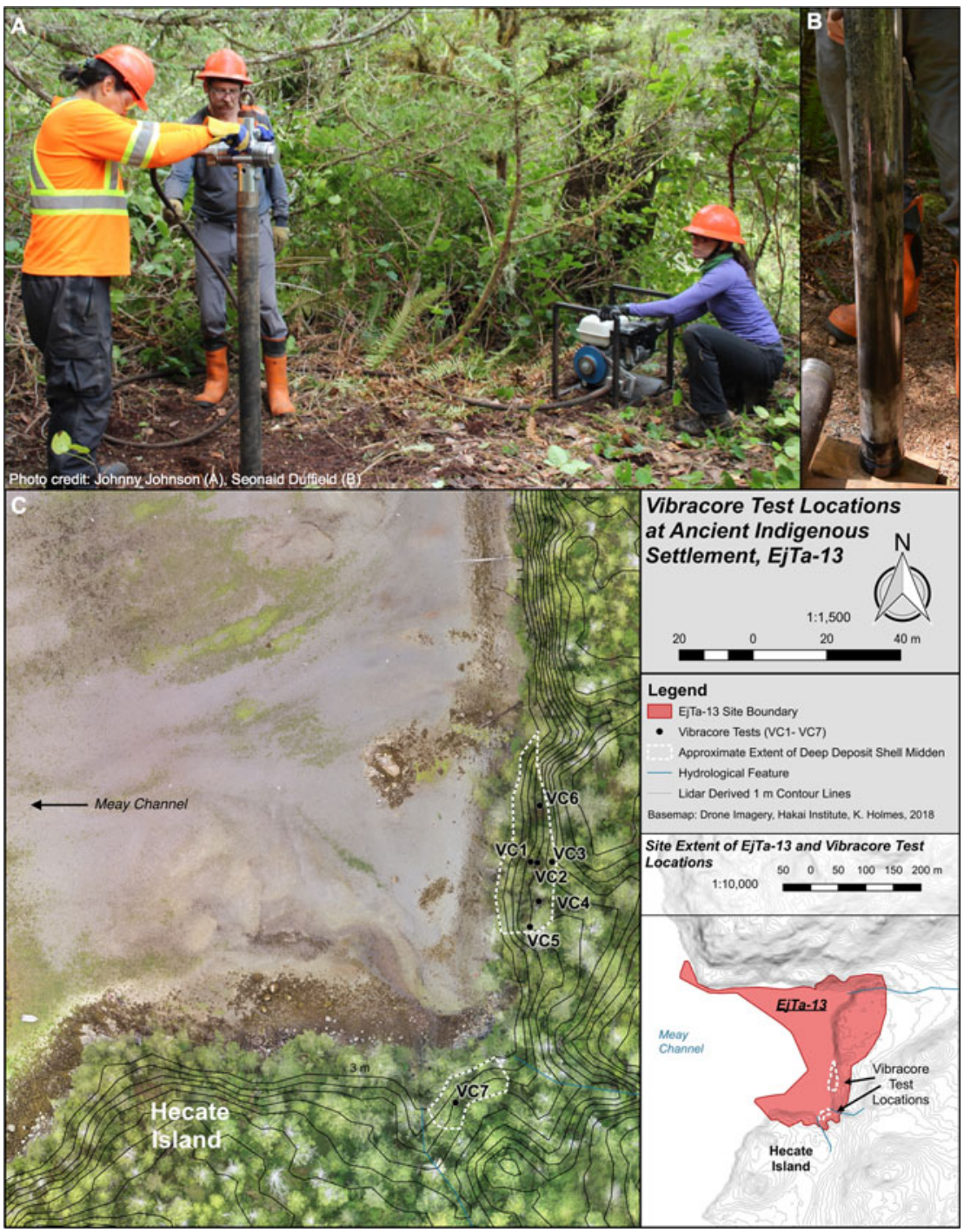

Figure 2. (A) Maxwell Johnson Jr. (Heiltsuk community member) operating the vibracore, while archaeologist John Maxwell directs the "flexcable," which feeds rotational power from the motor to the drill head, and Seonaid Duffield operates the motor (photo courtesy of Johnny Johnson, Wuikinuxv Nation); (B) an example of a vibracore sample tube containing a sediment sample (photo courtesy of Seonaid Duffield); (C) map of test locations at EjTa-13 (created by Seonaid Duffield).

(Pacific herring, salmon species, rockfish species, and greenling species) across the site. All other identified fish taxa represent $2 \%$ or less of the overall NISP, totaling 442 identified elements (Table 2). Calculations of ubiquity across all core sections containing identified fauna ${ }^{3}(n=311)$ indicate that herring $(76 \%)$ and salmon $(75 \%)$ are the two most ubiquitous taxa, closely followed by rockfish $(56 \%)$; greenling (42\%); flatfish (15\%); dogfish and sablefish (11\%); sculpin (6\%); anchovy (4\%); ratfish and halibut (3\%); cod and pollock (2\%); and lingcod, eulachon, skate, and sardine (1\%).

\section{Estimated Depth below Surface Measurements Plotted with Radiocarbon Dates}

Dates from multiple core samples indicate a strong linear relationship $\left(\mathrm{R}^{2}=0.82\right)$ between age and depth below surface for all dated samples. Core VC3 had a slower rate of accumulation and also 
Table 1. Twenty-One Radiocarbon Dates Using Charcoal from Six Vibracore Samples and Two Auger Tests.

\begin{tabular}{|c|c|c|c|c|c|c|c|c|}
\hline $\begin{array}{l}\text { Borden } \\
\text { Number }\end{array}$ & $\begin{array}{l}\text { UCIAMS } \\
\text { Lab Code }\end{array}$ & $\begin{array}{l}\text { Core } \\
\text { Name }\end{array}$ & ${ }^{14} \mathrm{C}$ Age & $+/-$ & $\begin{array}{c}1 \sigma \text { Calibrated } \\
\text { Results (cal BP) }\end{array}$ & $\begin{array}{l}\text { Median Probability } \\
\text { cal } \mathrm{BP}^{\mathrm{a}}\end{array}$ & $\begin{array}{c}\text { Core } \\
\text { Measurement }(\mathrm{cm})\end{array}$ & $\begin{array}{c}\text { Purpose of } \\
\text { Radiocarbon } \\
\text { Date }\end{array}$ \\
\hline EjTa-13 & 163718 & $\mathrm{VC} 1$ & 1240 & 20 & $1127-1145$ & 1161 & $7-8$ & Top of cultural deposit \\
\hline EjTa-13 & 163719 & $\mathrm{VC} 1$ & 2170 & 15 & $2124-2152$ & 2243 & $37-38$ & Clear stratigraphic break \\
\hline EjTa-13 & 163720 & $\mathrm{VC} 1$ & 2525 & 15 & $2541-2724$ & 2620 & $47-50$ & Clear stratigraphic break \\
\hline EjTa-13 & 163721 & $\mathrm{VC} 1$ & 2950 & 20 & $3074-3156$ & 3112 & $65-68$ & Middle of large layer \\
\hline EjTa-13 & 163722 & $\mathrm{VC} 1$ & 3135 & 20 & $3277-3383$ & 3365 & $85-86$ & Clear stratigraphic break \\
\hline EjTa-13 & 163723 & $\mathrm{VC} 1$ & 3195 & 20 & $3390-3447$ & 3416 & $78-80$ & Clear stratigraphic break \\
\hline EjTa-13 & 163724 & $\mathrm{VC} 1$ & 3970 & 20 & $4414-4509$ & 4443 & $109-110$ & Clear stratigraphic break \\
\hline EjTa-13 & 163725 & $\mathrm{VC} 1$ & 4070 & 20 & $4451-4776$ & 4551 & $127-128$ & Clear stratigraphic break \\
\hline EjTa-13 & 163726 & $\mathrm{VC} 1$ & 4165 & 25 & $4626-4823$ & 4710 & $131.5-136.5$ & Clear stratigraphic break \\
\hline EjTa-13 & 163727 & $\mathrm{VC} 1$ & 4405 & 20 & $4883-5037$ & 4969 & $136.5-141.5$ & Bottom of cultural deposit \\
\hline EjTa-13 & 179720 & VC3 & 860 & 15 & $731-772$ & 757 & $0-5$ & Top of cultural deposit \\
\hline EjTa-13 & 179721 & VC3 & 4725 & 15 & $5331-5554$ & 5464 & $135-140$ & Bottom of cultural deposit \\
\hline EjTa-13 & 179722 & $\mathrm{VC} 4$ & 415 & 15 & $481-503$ & 494 & $5-10$ & Top of cultural deposit \\
\hline EjTa-13 & 179723 & $\mathrm{VC} 4$ & 4915 & 15 & $5598-5651$ & 5635 & $380-385$ & Bottom of cultural deposit \\
\hline EjTa-13 & 179724 & VC5 & 345 & 15 & $322-456$ & 379 & $10-15$ & Top of cultural deposit \\
\hline EjTa-13 & 179725 & VC5 & 5080 & 20 & $5755-5899$ & 5809 & $478-481^{\mathrm{b}}$ & Bottom of cultural deposit \\
\hline EjTa-13 & 179726 & VC6 & 715 & 15 & $663-673$ & 669 & $10-15$ & Top of cultural deposit \\
\hline EjTa-13 & 179727 & VC6 & 3430 & 20 & $3638-3812$ & 3673 & $245-248.5$ & Bottom of cultural deposit \\
\hline EjTa-13 & 179728 & VC7 & 335 & 15 & $318-445$ & 381 & $0-5$ & Top of cultural deposit \\
\hline EjTa-13 & 179729 & VC7 & 3145 & 15 & $3359-3388$ & 3374 & 189-191 & Bottom of cultural deposit \\
\hline EjTa-13 & 186384 & VC7 & 4925 & 15 & $5600-5653$ & 5635 & $335-339^{6}$ & Bottom of cultural deposit \\
\hline
\end{tabular}

Note: Calibrations were calculated with Calib 8.2 (Stuiver et al. 2021) using the IntCal20 curve (Reimer et al. 2020).

${ }^{\mathrm{a}}$ Median probability estimated by Calib 8.2 .

${ }^{b}$ Charcoal removed from auger sample (dbs). 

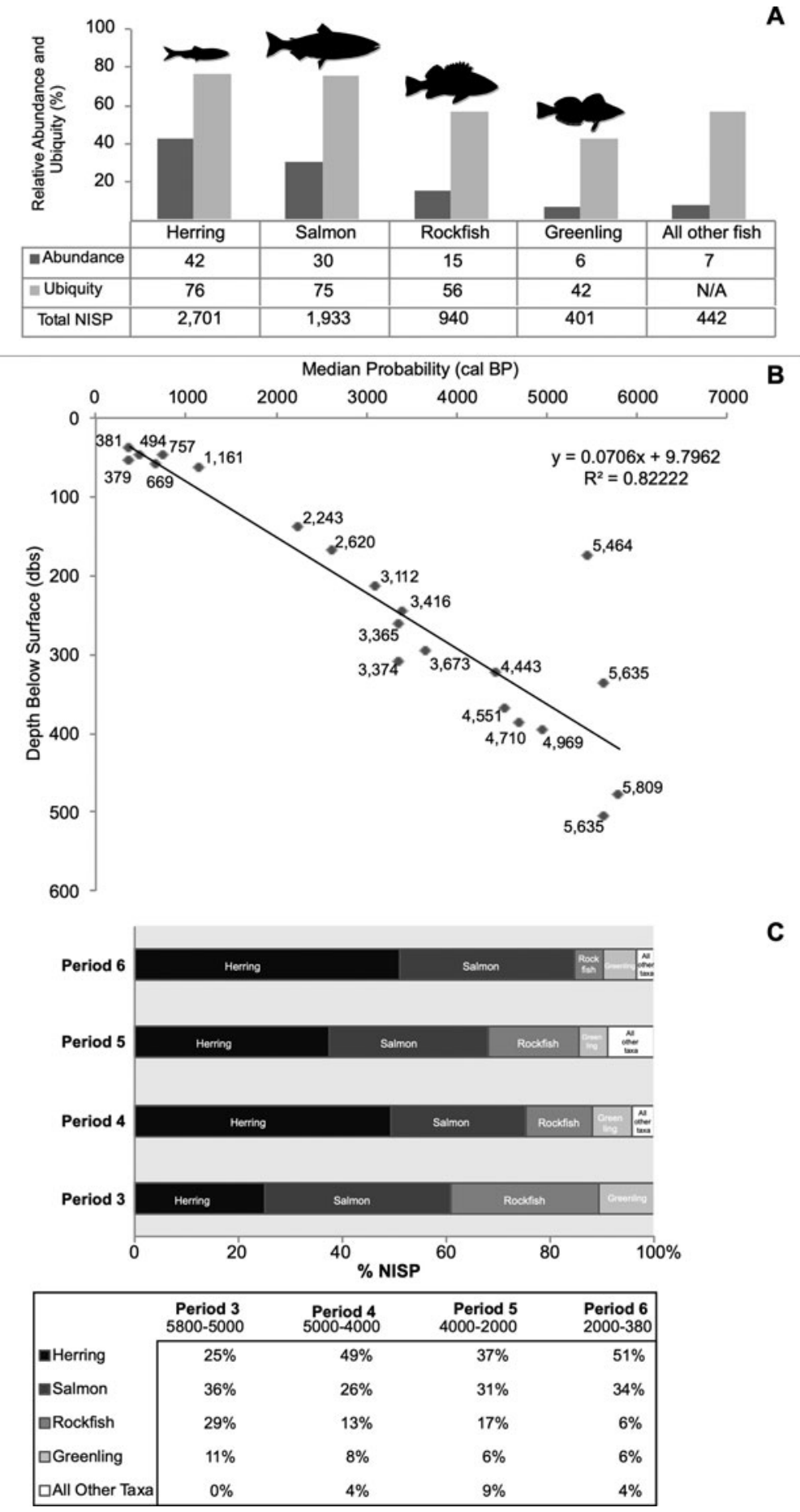

C

Figure 3. (A) ubiquity and relative abundance of the four most numerous fish taxa and all other fish with NISP ( $2 \mathrm{~mm}$ screen size); (B) plot of radiocarbon dates against depth below surface from all dated core samples (the estimated dbs measurements of charcoal samples used for radiocarbon dating were determined by calculating compaction for individual core samples)—numbers indicate the midpoint of the calibrated range; $(\mathrm{C})$ chart showing relative abundance (\%) of the most abundant fish taxa and all other fish taxa at EjTa-13 by time period. 
Table 2. Results from 2 mm Sized Screened Fauna: NISP, NISP Percentage, NSP, Age Range, and Estimated Volume per Core, and Overall Volume.

\begin{tabular}{|c|c|c|c|c|c|c|c|c|c|c|c|c|c|c|c|c|c|}
\hline \multirow[b]{3}{*}{ Taxa } & \multirow[b]{3}{*}{ Common Name } & \multicolumn{14}{|c|}{ Vibracore Samples } & \multirow[b]{3}{*}{ Total NISP } & \multirow[b]{3}{*}{$\%$ NISPFish } \\
\hline & & \multicolumn{2}{|c|}{$\mathrm{VC} 1$} & \multicolumn{2}{|c|}{$\mathrm{VC} 2$} & \multicolumn{2}{|c|}{ VC3 } & \multicolumn{2}{|c|}{$\mathrm{VC} 4$} & \multicolumn{2}{|c|}{ VC5 } & \multicolumn{2}{|c|}{ VC6 } & \multicolumn{2}{|c|}{ VC7 } & & \\
\hline & & NISP & $\%$ & NISP & $\%$ & NISP & $\%$ & NISP & $\%$ & NISP & $\%$ & NISP & $\%$ & NISP & $\%$ & & \\
\hline Clupea pallasii & Herring & 136 & 55 & 433 & 50 & 196 & 57 & 423 & 28 & 591 & 47 & 652 & 45 & 268 & 38 & 2,701 & 42.00 \\
\hline Oncorhynchus sp. & Salmon & 79 & 32 & 217 & 25 & 91 & 27 & 658 & 43 & 370 & 29 & 272 & 19 & 246 & 34 & 1,933 & 30.00 \\
\hline Sebastes sp. & Rockfish & 13 & 5 & 116 & 13 & 37 & 11 & 161 & 11 & 166 & 13 & 350 & 24 & 97 & 14 & 940 & 14.00 \\
\hline Hexagrammos sp. & Greenling & 11 & 4 & 72 & 8 & 10 & 3 & 100 & 7 & 97 & 8 & 82 & 6 & 29 & 4 & 401 & 6.00 \\
\hline Anoplopoma fimbria & Sablefish & 0 & & 6 & $<1$ & 1 & $<1$ & 40 & 3 & 11 & $<1$ & 34 & 2 & 32 & 5 & 124 & 2.00 \\
\hline Sardinops sagax caerulea & Sardine & 0 & & 0 & & 0 & & 84 & 5 & 0 & & 0 & & 0 & & 84 & 1.00 \\
\hline Squalus acanthias & Spiny dogfish shark & 3 & 1 & 4 & $<1$ & 2 & $<1$ & 34 & 2 & 7 & $<1$ & 12 & $<1$ & 7 & 1 & 69 & 1.00 \\
\hline Pleuronectiformes & Flatfish & 0 & & 3 & $<1$ & 6 & $<1$ & 4 & $<1$ & 14 & 1 & 18 & 1 & 7 & 1 & 52 & 0.80 \\
\hline Engraulis mordax & Anchovy & 2 & $<1$ & 1 & $<1$ & 0 & & 1 & $<1$ & 3 & $<1$ & 0 & & 23 & 3 & 30 & 0.50 \\
\hline Hemilepidotus spp. & Irish lord & 1 & $<1$ & 4 & $<1$ & 0 & & 5 & $<1$ & 0 & & 7 & $<1$ & 0 & & 17 & 0.30 \\
\hline Hydrolagus colliei & Spotted ratfish & 0 & & 0 & & 0 & & 4 & $<1$ & 1 & $<1$ & 9 & $<1$ & 0 & & 14 & 0.20 \\
\hline Hippoglossus & Pacific halibut & 3 & 1 & 7 & $<1$ & 0 & & 2 & $<1$ & 1 & $<1$ & 0 & & 0 & & 13 & 0.20 \\
\hline Gadus & Pollock and Pacific cod & 0 & & 1 & $<1$ & 0 & & 0 & & 3 & $<1$ & 1 & $<1$ & 5 & $<1$ & 10 & 0.20 \\
\hline Lepidopsetta bilineata & Rock sole & 0 & & 1 & $<1$ & 0 & & 2 & $<1$ & 0 & & 3 & $<1$ & 0 & & 6 & 0.09 \\
\hline Cottoidea & Sculpin & 1 & $<1$ & 0 & & 0 & & 1 & $<1$ & 0 & & 2 & $<1$ & 0 & & 4 & 0.06 \\
\hline Ophiodon elongatus & Lingcod & 0 & & 0 & & 0 & & 3 & $<1$ & 1 & $<1$ & 0 & & 0 & & 4 & 0.06 \\
\hline Parophrys vetulus & English Sole & 0 & & 3 & $<1$ & 0 & & 0 & & 0 & & 0 & & 0 & & 3 & 0.05 \\
\hline Pholidae & Gunnel & 0 & & 3 & $<1$ & 0 & & 0 & & 0 & & 0 & & 0 & & 3 & 0.05 \\
\hline Thaleichthys pacificus & Eulachon & 0 & & 0 & & 0 & & 0 & & 2 & $<1$ & 0 & & 1 & $<1$ & 3 & 0.05 \\
\hline Raja sp. & Skate & 0 & & 0 & & 0 & & 2 & $<1$ & 0 & & 0 & & 0 & & 2 & 0.03 \\
\hline Enophrys bison & Buffalo sculpin & 0 & & 0 & & 0 & & 1 & $<1$ & 0 & & 1 & $<1$ & 0 & & 2 & 0.03 \\
\hline Atheresthes stomias & Arrowtooth flounder & 0 & & 0 & & 0 & & 1 & $<1$ & 0 & & 0 & & 0 & & 1 & 0.02 \\
\hline Gadus chalcogrammus & Walleye pollock & 0 & & 0 & & 0 & & 0 & & 1 & $<1$ & 0 & & 0 & & 1 & 0.02 \\
\hline
\end{tabular}


Table 2. Continued.

\begin{tabular}{|c|c|c|c|c|c|c|c|c|c|c|c|c|c|c|c|c|c|}
\hline \multirow[b]{3}{*}{ Taxa } & \multirow[b]{3}{*}{ Common Name } & \multicolumn{14}{|c|}{ Vibracore Samples } & \multirow[b]{3}{*}{ Total NISP } & \multirow[b]{3}{*}{$\%$ NISPFish } \\
\hline & & \multicolumn{2}{|c|}{$\mathrm{VC1}$} & \multicolumn{2}{|c|}{$\mathrm{VC} 2$} & \multicolumn{2}{|c|}{ VC3 } & \multicolumn{2}{|c|}{ VC4 } & \multicolumn{2}{|c|}{ VC5 } & \multicolumn{2}{|c|}{ VC6 } & \multicolumn{2}{|c|}{ VC7 } & & \\
\hline & & NISP & $\%$ & NISP & $\%$ & NISP & $\%$ & NISP & $\%$ & NISP & $\%$ & NISP & $\%$ & NISP & $\%$ & & \\
\hline Neovison vison & Mink & 0 & & 3 & & 0 & & 1 & & 0 & & 0 & & 0 & & 4 & N/A \\
\hline Odocoileus sp. & Deer & 0 & & 0 & & 0 & & 0 & & 2 & & 0 & & 0 & & 2 & N/A \\
\hline Canis familiaris & Domestic dog & 0 & & 0 & & 0 & & 1 & & 1 & & 0 & & 0 & & 2 & N/A \\
\hline Lontra canadensis & River otter & 0 & & 1 & & 0 & & 0 & & 0 & & 0 & & 0 & & 1 & N/A \\
\hline Enhydra lutris & Sea otter & 0 & & 0 & & 0 & & 1 & & 0 & & 0 & & 0 & & 1 & N/A \\
\hline Phoca vitulina & Harbor seal & 0 & & 1 & & 0 & & 0 & & 0 & & 0 & & 0 & & 1 & N/A \\
\hline Soricidae & Shrew & 1 & & 0 & & 0 & & 0 & & 0 & & 0 & & 0 & & 1 & N/A \\
\hline Castor canadensis & North American beaver & 0 & & 0 & & 0 & & 0 & & 1 & & 0 & & 0 & & 1 & N/A \\
\hline Tamiasciurus douglasii & Douglas squirrel & 0 & & 0 & & 0 & & 0 & & 0 & & 0 & & 1 & & 1 & N/A \\
\hline Mammalia & Sm. unid. land mammal ${ }^{\mathrm{a}}$ & 0 & & 0 & & 1 & & 0 & & 0 & & 0 & & 0 & & 1 & N/A \\
\hline Mammalia & Lg. unid. land mammal ${ }^{b}$ & 0 & & 0 & & 0 & & 1 & & 1 & & 0 & & 0 & & 2 & N/A \\
\hline Mammalia & Unidentified mammal & 32 & & 105 & & 57 & & 179 & & 197 & & 74 & & 100 & & 74 & N/A \\
\hline Mammalia/Aves & Small mammal or bird & 0 & & 0 & & 0 & & 1 & & 1 & & 1 & & 0 & & 3 & N/A \\
\hline Alcidae & Alcid & 0 & & 0 & & 0 & & 1 & & 0 & & 0 & & 0 & & 1 & N/A \\
\hline Podicipedidae & Large grebe & 0 & & 0 & & 0 & & 0 & & 0 & & 0 & & 1 & & 1 & N/A \\
\hline \multirow[t]{11}{*}{ Aves } & Unidentified bird & 7 & & 6 & & 0 & & 8 & & 1 & & 0 & & 0 & & 22 & N/A \\
\hline & Unidentified bone & 0 & & 0 & & 0 & & 0 & & 0 & & 34 & & 0 & & 34 & N/A \\
\hline & Fish NISP & 249 & & 871 & & 343 & & 1,528 & & 1,268 & & 1,443 & & 715 & & 6,417 & \\
\hline & Fish NSP & 542 & & 1,653 & & 432 & & 2,575 & & 1,900 & & 2,559 & & 1,059 & & 10,720 & \\
\hline & Total & 831 & & 2,640 & & 833 & & 4,296 & & 3,372 & & 4,111 & & 1,876 & & 17,959 & \\
\hline & Age Range $(1 \sigma \text { cal BP })^{\mathrm{c}}$ & $1230-5040$ & 1230 & -5040 & 730 & -5550 & 480 & -5650 & 320 & -5890 & 660 & -3810 & 320 & -5650 & & $320-5900$ & \\
\hline & No. of Sections $(5 \mathrm{~cm})$ & 25 & & 51 & & 24 & & 70 & & 61 & & 41 & & 39 & & 311 & \\
\hline & Estimated Volume (L) & $9 \mathrm{~L}$ & & $18 \mathrm{~L}$ & & $10 \mathrm{~L}$ & & $22 \mathrm{~L}$ & & $18 \mathrm{~L}$ & & $11 \mathrm{~L}$ & & $12 \mathrm{~L}$ & & $100 \mathrm{~L}$ & \\
\hline & Fish NSP per Liter & 60 & & 92 & & 43 & & 117 & & 106 & & 233 & & 88 & & & \\
\hline & Fish NISP per Liter & 28 & & 48 & & 34 & & 70 & & 70 & & 131 & & 60 & & & \\
\hline & $N$ TAXA (Fish) & 9 & & 14 & & 7 & & 18 & & 14 & & 13 & & 10 & & & \\
\hline
\end{tabular}

a Small unidentified land mammal.
${ }^{\mathrm{b}}$ Large unidentified land mammal.

${ }^{\mathrm{c}}$ Calibrated age range based on Table 1. 
contained the lowest frequency of shell and fauna, and it is an outlier (see Supplemental Text 1 and Supplemental Figure 8 for the ratio of compression and accumulation estimates). The strong linear relationship reflected by the $\mathrm{R}^{2}$ value may be influenced by the large number of dates in VC1 versus smaller numbers in the other cores. It is also probable that all sediments were not compressed equally (e.g., basal deposits may be more compressed than those closer to the surface). Despite these limitations, Figure 3B demonstrates that broad-scale site formation processes exhibit striking similarities across core locations with relative uniformity across six millennia of regular human use. Accordingly, fauna from multiple core samples can be used to estimate age using depth to interpret trends over time.

\section{Evaluating Temporal Trends}

To explore temporal patterning in zooarchaeological data at EjTa-13 and evaluate the trends in relation to other sites in the region, we compare calibrated ages and depths to define large chronological intervals comparable with Namu, a well-dated site with a detailed zooarchaeological record spanning 6,000 years. At Namu, researchers conducted multiple seasons of excavations in different areas of the site to develop a Holocene archaeological sequence, including an extensive faunal assemblage where bone was preserved in the matrix (Cannon 1991, 2000a; Carlson 1991). Significantly, the chronology of fauna represented at EjTa-13 has similarities to that of Namu (6000 cal BP to contact). This provides an opportunity to compare millennial-scale faunal trends over time in two separate sites in relatively close proximity on the Central Coast (only $25 \mathrm{~km}$ apart, or $33 \mathrm{~km}$ by boat).

Carlson (1991) devised a chronological framework based on a combination of stratigraphy, distribution of artifacts and fauna, and 31 radiocarbon dates to identify six time periods across multiple areas of the site. ${ }^{4}$ The earliest period at Namu with preserved fauna (Period 3) overlaps with the earliest component at EjTa-13 (5800-5000 cal BP), and subsequent time periods (Periods 4-6) span the past 5,000 years to contact and provide four broad periods for temporal comparison. The accumulation rate estimates from EjTa-13 were used to derive equivalent time periods. Carlson's (1991) previously uncalibrated radiocarbon dates were calculated with Calib 8.2 (Stuiver et al. 2021) using the IntCal20 curve (Reimer et al. 2020). Cannon and colleagues $(2011)^{5}$ use these time periods to analyze salmon and herring ( $2 \mathrm{~mm}$ screen size) from Namu, and as a result, these same time periods were used to analyze EjTa-13 data for the purpose of consistency between sites.

The earliest and latest time periods at EjTa-13 (5800-5000 cal BP and 2000-380 cal BP, respectively) show that the least amount of fish remains were identified per liter from these two periods. The earliest period was also poorly represented in terms of number of examined liters (3.8 L). Only VC3, VC4, and VC5 contained sediments that were determined to be between 5800 and 5000 cal BP.

The four most abundant and ubiquitous taxa in the EjTa-13 assemblage are herring, salmon, rockfish, and greenling, respectively (Figure 3C). The prominence of these fish in terms of their proportional abundance and regular occurrence in multiple depositional contexts illustrates a remarkable continuity of fish use through time, similar to the broad-scale patterning at Namu. Herring and salmon are dominant throughout the sequence, with the exception of the earliest period, when rockfish numerically displace herring with a slightly higher relative abundance value. The combined abundance of herring and salmon are highest in the latest period. Period 5 (ca. 4000-2000 cal BP) has a slight increase in the category "all other fish taxa." 6

EjTa-13 has a notably higher abundance of herring and a lower abundance of salmon in comparison with the site of Namu (Figure 4). Namu is situated at the mouth of a productive salmon river, which likely accounts for a higher abundance of salmon bones. The extensive history of archaeological investigations at Namu and long-term temporal record have been used to highlight the importance of stable salmon fisheries in the rise of early Holocene winter villages among other settlement patterns (Cannon 1991, 2000a, 2001b; Cannon and Yang 2011; Cannon et al. 2011). 


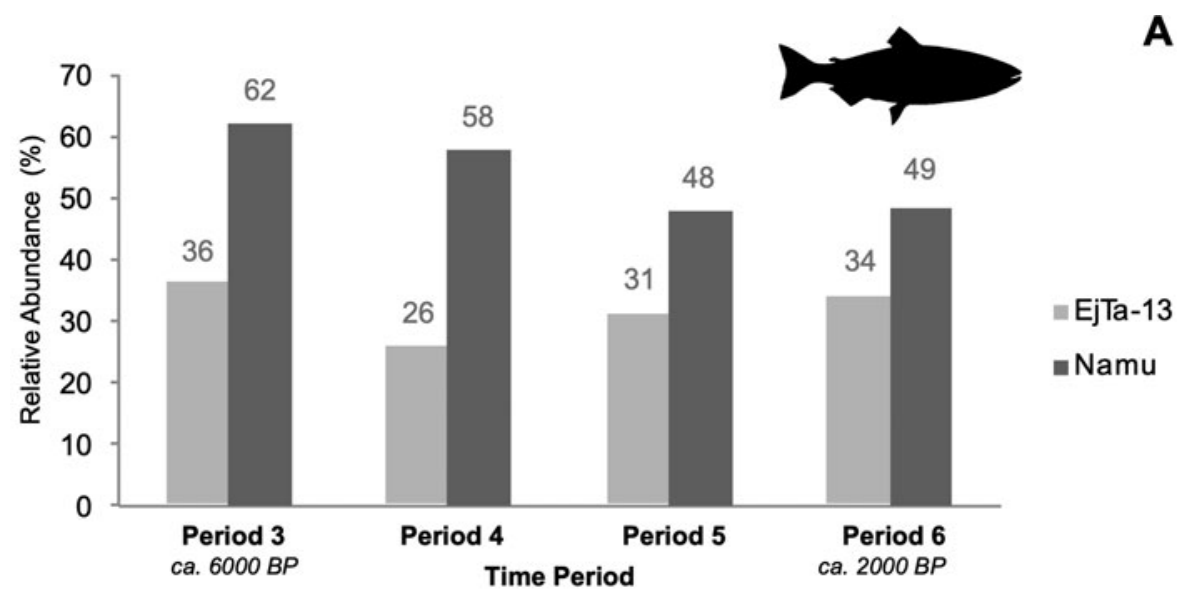

A

B

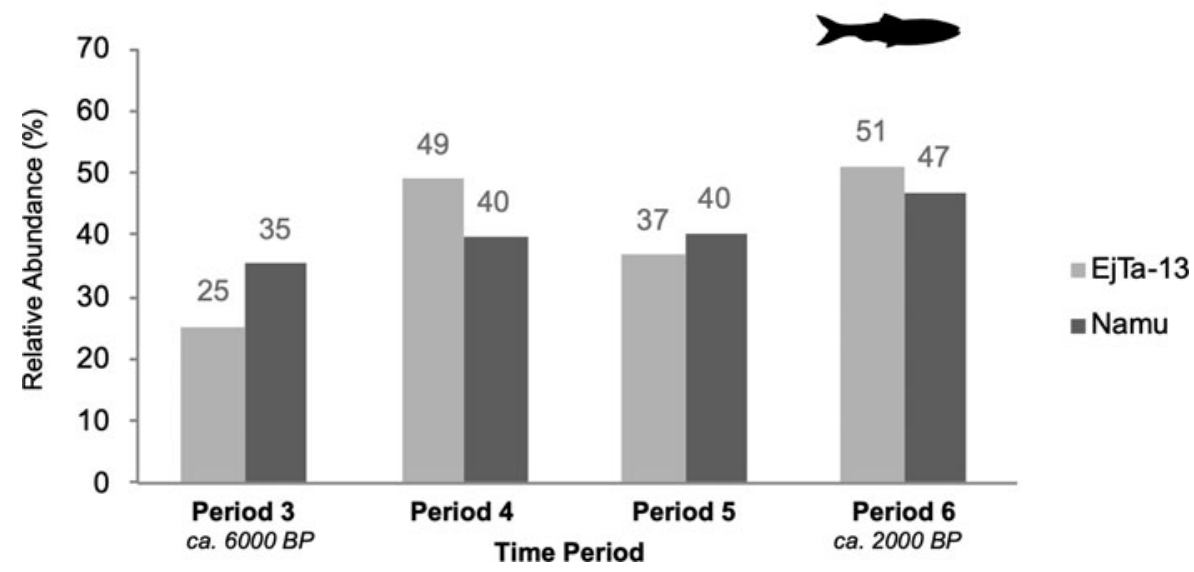

Figure 4. (A) trends in salmon from Namu and EjTa-13 by Namu time period (Namu data adapted from Cannon et al. 2011:62, Table 5.1); (B) trends in herring from Namu and EjTa-13 by Namu time period (Namu data adapted from Cannon et al. 2011:62, Table 5.1).

EjTa-13 has an even higher number of dates and temporal resolution from which the longevity of fish availability and successful management can be drawn for similar interpretations on a broader geographic scale.

Comparison of herring bone from EjTa-13 and Namu by time period shows remarkable similarity and suggests continuity of marine resource use between sites (Figure 4A). Comparable to salmon, herring bones are continuously represented throughout the faunal assemblages at EjTa-13 and at Namu, reflecting a persistence of use of these taxa throughout the site occupation. Herring is regionally high ranking in abundance and ubiquity among Central Coast sites (Cannon 2000b; McKechnie et al.
2014). These results highlight the efficiencies of using this methodology to understand trends through time.

\section{Artifact Recovery}

A total of 55 artifacts (including lithic debitage) were located within approximately $100 \mathrm{~L}$ of cultural sediments during the sorting and faunal identification phases of the project (Figure 5). This amounts to an estimated artifact density of 550 artifacts per $\mathrm{m}^{3}$. These estimates are far higher than artifact densities at other shell midden sites on the Northwest Coast that have not been subject to wet screening or fine-mesh recovery (cf. Ames 2005; McMillan and St. Claire 2005). See Supplemental Text 1 for additional 

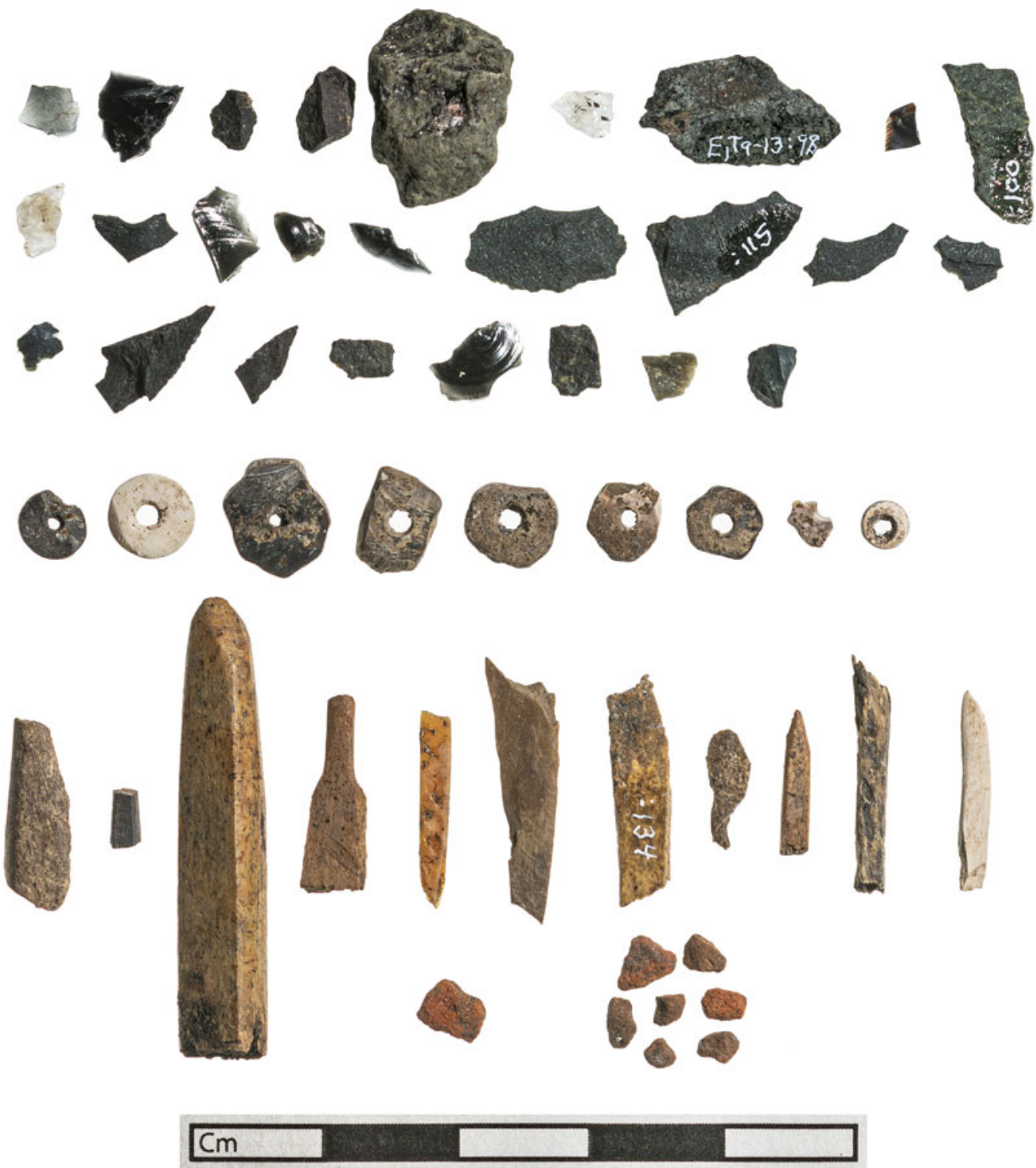

Figure 5. A selection of artifacts recovered from vibracore core samples within EjTa-13. (Photo courtesy of Andrew Eckert.)

information about artifact recovery from EjTa-13 core samples.

\section{Discussion}

\section{Effectiveness of Coring}

Vibracore technology proved to be a useful methodology for establishing chronology, recovering fine-screen fauna and artifacts, and documenting stratigraphy. This makes this technology superior to a combination of auger sampling and percussion coring, and it preserves sediments within a single sample tube. In contexts where obtaining stratigraphically intact samples from multiple areas of a large shell midden is needed, vibracoring would be ideal. However, it is also the case that there are some challenges and limitations of the technology. For example, vibracoring was less successful in paleobeach sediments consisting of a mix of sand, gravels, and cobbles 
where cores were not collected as quickly as in other, softer silty sediments and where more machine running time was required to complete the test. In some instances where the crew was met with rock refusal, the coring unit was withdrawn, and the test was resumed using a bucket auger instead, which was often effective in dislodging an obstruction, thereby allowing vibracoring to proceed. Typically, samples terminated in a rock refusal or when cores reached blue-gray, fine-silty clay, characteristic of glacial-proximal minerogenic sediments in the region. Using an auger is therefore an effective solution for finishing tests in difficult sediments because the vibracore leaves a "neat" test hole into which an auger fits easily.

The expense of the coring unit itself (upfront cost approximately $\$ 15,000 \mathrm{CDN}$ ), in addition to ongoing maintenance that involves transporting heavy components, is another major consideration. The bulk and weight of the composite system (approximately $136 \mathrm{~kg}$ or $300 \mathrm{lbs}$.) is a challenge for transporting the machine to remote and difficult-to-access field sites, and this is exacerbated by the added weight and care needed in transporting recovered $1.52 \mathrm{~m}$ core samples upright. In this study, the site was easily accessible by a 15-minute boat ride from the Hakai Institute's Ecological Observatory on Calvert Island, but it required transportation logistics that would otherwise be extremely costly and impractical for informal exploratory surveys. Finally, the device requires a strong, able-bodied, and mechanically minded three-person crew for efficient and safe sample recovery.

Further logistical considerations include the large amount of time spent during the postrecovery processing of cores (e.g., documenting stratigraphy, washing sediments, and picking the fauna) as well as the faunal identification phase of the project. Dividing the core samples into $5 \mathrm{~cm}$ vertical sections involved a significant time investment.

Overall, fauna was analyzed from 311 individual $5 \mathrm{~cm}$ sections, resulting in a total assemblage of 17,959 bones specimens. A total of $35.7 \%$ of specimens were identified to species, genus, or family level, with the remainder being assigned to more general taxonomic categories (i.e., order, class). Identifying fauna from the assemblage took one nonexpert an estimated six months, so approximately 3,000 bones were analyzed per month (1,070 identified bones/month).

Other considerations include the potential to recover ancestral remains within the core sample inadvertently. Ancestral remains were encountered in a single vibracore sample. Following direct guidance from Indigenous team members, ancestral remains were carefully wrapped, minimally handled, and reburied on-site. Detailed work has since established that no other ancestral remains had been inadvertently disturbed. Protocols and process relating to this are further described in Duffield (2017).

\section{Regional Contextualization}

The archaeologically observed Indigenous fishing practices presented in this article are relatively consistent with what other archaeologists have observed elsewhere on the Northwest Coast in general and on the Central Coast in particular over the past 5,000 years (Cannon 2013; McKechnie and Moss 2016). For instance, the overall ubiquity and mean rank order of salmon and herring are strongly consistent between Namu and EjTa-13, and these remain the two most important fish taxa identified at sites on the Central Coast. Such stability indicates durable patterns of resource use over millennial time scales among contemporaneously occupied archaeological sites. Such persistent practices have implications for present-day management strategies in this region, where commercial fishing practices specific to herring and all five coastal salmon species remain a conservation concern (Okamoto et al. 2019; Walsh et al. 2020). Present-day management strategies may include community-based management or Indigenous stewardship programs of fish taxa found in the archaeological record over millennia (Ban et al. 2020; Quintana Morales et al. 2017). Although vibracore sampling at EjTa-13 highlights broad-scale changes through time, it is clear that availability of key resources persisted in similar abundances through millennia. ${ }^{7}$

\section{Conclusion}

This study investigated the utility of vibracore technology at a mid to late Holocene shell 
midden site on the Central Coast of British Columbia. Archaeological sediments obtained from core samples were used to generate zooarchaeological data and investigate fisheries' resource use through time and in comparison to the intensively studied archaeological site of Namu (ElSx-1). A considerable amount of lithic debitage and artifacts was also recovered. Continuity of resource use over millennial scales was observed at EjTa-13 through the four most abundant and ubiquitous fish taxa: herring, salmon, rockfish, and greenling. Similar to Namu, this indicates that certain resources were preferentially targeted over 5,800 years at EjTa-13. A number of other fish, bird, and mammal taxa-as well as shellfish-were also regularly present (Duffield 2017). Further analysis of these persistently occurring taxa can expand perspective on the range of resource use, technologies, and social practices over time and throughout multiple areas of the site.

The proportional abundance of fish remains within shell-bearing Northwest Coast archaeological sites is indicative of a diet rich in marine resources. At EjTa-13, fish taxa contributed to $99 \%$ of the identified vertebrate faunal remains recovered from the vibracore samples in fine screens. The abundance of fish, especially in comparison to mammal and bird, indicates that fish were caught and consumed with high regularity, both for immediate consumption and presumably long-term storage as culturally preferred taxa. These results are illustrative of the effectiveness of vibracore technology in showing longterm patterns of fisheries management through time. This technology is therefore another viable option for collecting information about broad trends of subsistence.

Vibracore sampling and radiocarbon dating documented relatively consistent accumulation rates between core samples and created flexible estimates of time periods. Further refinement of time periods could be accomplished given the strength of the relationship. We analyzed fish bones using existing Namu time periods with fish remains from within samples from EjTa-13 and with Namu data (Cannon et al. 2011). Despite the logistical and analytical challenges, vibracoring holds great promise for future research efforts in coastal shell middens, particularly for recovering small-scale zooarchaeological samples such as ancient fisheries and shellfisheries.

Acknowledgments. Thanks to Heiltsuk Nation and Wuikinuxv Nation for supporting this project. Thanks also to the Tula Foundation cofounders Christina Munck and Eric Peterson for financial support of the project. Thanks to Rebecca Wigen of Pacific Identifications Inc. for assistance with faunal identifications. Duncan McLaren facilitated archaeological investigations and the overarching Hakai Ancient Landscapes Archaeology Project under Heritage Conservation Act, permit 2011-171. Further financial support was also provided through a Hakai / Mitacs Accelerate Fellowship (facilitated by Iain McKechnie) and the University of Victoria Department of Anthropology graduate program. Thanks to Keith Holmes (Hakai Institute) for cartographic assistance and drone imagery, including access to lidar, and to Andrew Eckert for the artifact photo. Many thanks to Callum Abbott, Darcy Mathews, Duncan McLaren, Alex Nuchini, and Brittany Witherspoon (in 2015); and to Johnny Johnson, Maxwell Johnson Jr., and John Maxwell (in 2016) for operating the vibracore. We also thank the staff and support personnel at the Hakai Institute, Calvert Island Ecological Observatory. Finally, thanks to Ariel Reyes Antuan for translating the Spanish abstract, and to Debra Martin and an anonymous reviewer for helpful feedback.

Data Availability Statement. The data presented in this report was originally submitted as part of the primary author's master's thesis, which can be accessed through a University of Victoria website: https://dspace.library.uvic.ca//handle/ $1828 / 8936$.

Supplemental Material. For supplemental material accompanying this article, visit https://doi.org/10.1017/aaq.2021.113.

Supplemental Figure 1. EjTa-13 Vibracore Sample VC1 Core Profile.

Supplemental Figure 2. EjTa-13 Vibracore Sample VC2 Core Profile.

Supplemental Figure 3. EjTa-13 Vibracore Sample VC3 Core Profile.

Supplemental Figure 4. EjTa-13 Vibracore Sample VC4 Core Profile.

Supplemental Figure 5. EjTa-13 Vibracore Sample VC5 Core Profile.

Supplemental Figure 6. EjTa-13 Vibracore Sample VC6 Core Profile.

Supplemental Figure 7. EjTa-13 Vibracore Sample VC7 Core Profile.

Supplemental Figure 8. A: Ratio of Compression for Individual Core Samples, B: Accummulation Rate per 100 years.

Supplemental Figure 9. Cumulative Number of Taxa and Different Taxa per Core Sample.

Supplemental Text 1. Laboratory Methods, Ratio of Compression, Accumulation Rates, Assessing Sample Adequacy Artifact Recovery, and Future Directions. 


\section{Notes}

1. The Vancouver-based Wink Vibracore Drill Company manufactures the vibracore (H string) used for this project.

2. VC2 was not sampled for radiocarbon dates due to its close proximity $(<2 \mathrm{~m})$ to the intensively dated core VC1.

3 . Core sections were only included if they contained bone specimens in the $2 \mathrm{~mm}$ fraction.

4. We have decided to omit radiocarbon dates obtained from ancestral remains as well as a date sourced from shell due to issues with using the marine curve.

5. In Table 5.1, Cannon and colleagues (2011:62) draw conclusions from a total NISP of 5,870, including salmon $(n=3,222)$, herring $(n=2,398)$ and "other" $(n=250)$.

6. See Supplemental Text 1 and Supplemental Figure 9 for assessing sample adequacy.

7. See Supplemental Text 1 for future research directions

\section{References Cited}

Ames, Kenneth M.

2005 The North Coast Prehistory Project Excavations in Prince Rupert Harbour, British Columbia: The Artifacts. BAR International Series 1342. British Archaeological Reports, Oxford.

Ban, Natalie C., Emma Wilson, and Doug Neasloss

2020 Historical and Contemporary Indigenous Marine Conservation Strategies in the North Pacific. Conservation Biology 34:5-14.

Cannon, Aubrey

1991 The Economic Prehistory of Namu: Patterns in Vertebrate Fauna. Simon Fraser University Archaeology Press, Burnaby, British Columbia.

1995 The Ratfish and Marine Resource Deficiencies on the Northwest Coast. Canadian Journal of Archaeology 19:49-60.

1996 The Early Namu Archaeofauna. In Early Human Occupation in British Columbia, edited by Roy L. Carlson and Luke Dalla Bona, pp. 103-110. UBC Press, Vancouver.

2000a Settlement and Sea-Levels on the Central Coast of British Columbia: Evidence from Shell Midden Cores. American Antiquity 65:67-77.

2000b Assessing Variability in Northwest Coast Salmon and Herring Fisheries: Bucket-Auger Sampling of Shell Midden Sites on the Central Coast of British Columbia. Journal of Archaeological Science 27:725-737.

2002 Sacred Power and Seasonal Settlement on the Central Northwest Coast. In Beyond Foraging and Collecting: Evolutionary Change in Hunter-Gatherer Settlement Systems, edited by Ben Fitzhugh and Junko Habu, pp. 311-338. Kluwer-Plenum Press, New York.

2013 Revealing the Hidden Dimensions of Pacific Northwest Coast Shell Middens. In Shell Energy: Mollusc Shells as Coastal Resources, edited by Geoff N. Bailey, Karen Hardy, and Abdoulaye Camara, pp. 21-34. Oxbow Books, Oxford

Cannon, Aubrey, and Dongya Y. Yang

2011 Pushing Limits and Finding Interpretive Balance: A Reply to Monks and Orchard. American Antiquity 76:585-595.

Cannon, Aubrey, Dongya Y. Yang, and Camilla F. Speller

2011 Site-Specific Salmon Fisheries on the Central Coast of British Columbia. In The Archaeology of North Pacific Fisheries, edited by Madonna. L. Moss and
Aubrey Cannon, pp. 57-74. University of Alaska Press, Fairbanks.

Carlson, Roy L.

1976 The 1974 Excavations at McNaughton Island. In Current Research Reports, Publication Number 3, edited by Roy L. Carlson, pp. 99-114. Department of Archaeology, Simon Fraser University, Burnaby, British Columbia.

1991 Appendix B: Namu Periodization and C-14 Chronology. In The Economic Prehistory of Namu: Patterns in Vertebrate Fauna, by Aubrey Cannon, pp. 85-95. Simon Fraser University Archaeology Press , Burnaby, British Columbia.

Casteel, Richard W.

1970 Core and Column Sampling. American Antiquity 35:465-467.

1976 Comparison of Column and Whole Unit Samples for Recovering Fish Remains. World Archaeology 8:192-196.

Conover, Kathryn J.

1972 Archaeological Sampling at Namu: A Problem in Settlement Reconstruction. PhD dissertation, Department of Anthropology, University of Colorado, Boulder.

1978 Matrix Analysis. In Studies in Bella Bella Prehistory, edited by James J. Hester and Sarah M. Nelson, pp. 67-100. Simon Fraser University Archaeology Press, Burnaby, British Columbia.

Drucker, Phillip

1943 Archeological Survey on the Northern Northwest Coast. Bulletin 133, No. 20. Bureau of American Ethnology, Smithsonian Institution, Washington, DC.

Duffield, Seonaid

2017 Long-Term Use of Fish and Shellfish Resources Revealed through Vibracore Sampling at EjTa-13, Hecate Island, Central Coast, BC. Master's thesis, Department of Anthropology, University of Victoria, Victoria, British Columbia.

Gray, Brendan

2008 Sampling Methods in Northwest Coast Household Archaeology: A Simulation Approach Using Faunal Data from the Ozette Site. Master's thesis, Department of Anthropology, University of Victoria, Victoria, British Columbia.

Hester, James J., and Sarah M. Nelson (editors)

1978 Studies in Bella Bella Prehistory. Simon Fraser University Archaeology Press, Burnaby, British Columbia.

Letham, Bryn

2014 Settlement and Shell-Bearing Site Diversity in the Sechelt Inlet System, British Columbia. Canadian Journal of Archaeology 38:280-328.

Letham, Bryn, Andrew Martindale, Kisha Supernant, Thomas J. Brown, Jerry S. Cybulski, and Kenneth M. Ames

2017 Assessing the Scale and Pace of Large Shell-Bearing Site Occupation in the Prince Rupert Harbour Area, British Columbia. Journal of Island and Coastal Archaeology 14:163-197.

Luebbers, Roger A

1971 Archaeological Sampling at Namu. Unpublished manuscript on file, Department of Anthropology, University of Colorado, Boulder.

Lyman, R. Lee

1991 Prehistory of the Oregon Coast: The Effects of Excavation Strategies and Assemblage Size on Archaeological Inquiry. Academic Press, Orlando, Florida.

Martindale, Andrew, Bryn Letham, Duncan McLaren, David Archer, Meghan Burchell, and Bernd R. Schone 
2009 Mapping of Subsurface Shell Midden Components through Percussion Coring: Examples from the Dundas Islands. Journal of Archaeological Science 36:15651575 .

McKechnie, Iain

2005 Column Sampling and the Archaeology of Small Fish at Ts'ishaa. In Ts'ishaa: Archaeology and Ethnography of a Nuu-chah-nulth Origin Site in Barkley Sound, by Alan D. McMillan and Denis E. St. Claire, pp. 206223. Simon Fraser University Archaeology Press, Burnaby, British Columbia.

2012 Zooarchaeological Analysis of the Indigenous Fishery at the Huu7ii Big House and Back Terrace, Huu-ayaht Territory, Southwestern Vancouver Island. Huи7ii: Household Archaeology at a Nuu-chah-nulth Village site in Barkley Sound, by Alan D. McMillan and Denis E. St. Claire, pp. 154-186. Simon Fraser University Archaeology Press, Burnaby, British Columbia.

2014 An Archaeology of Food and Settlement on the Northwest Coast. PhD dissertation, Department of Anthropology, University of British Columbia, Vancouver.

2015 Indigenous Oral History and Settlement Archaeology in Barkley Sound, Western Vancouver Island. BC Studies 187:193-228. DOI:10.14288/bcs.v0i187. 186162.

McKechnie Iain, Dana Lepofsky, Madonna Moss, Virginia L. Butler, Trevor J. Orchard, Gary Coupland, Fredrick Foster, Megan Caldwell, and Ken Lertzman

2014 Archaeological Data Provide Alternative Hypotheses on Pacific Herring (Clupea pallasii) Distribution, Abundance, and Variability. PNAS 111(9):E807-E816.

McKechnie, Iain, and Madonna Moss

2016 Meta-Analysis in Zooarchaeology Expands Perspectives on Indigenous Fisheries of the Northwest Coast of North America. Journal of Archaeological Science 8:470-485. DOI:10.1016/j.jasrep.2016.04.006.

McLaren, Duncan

2013 Report for the Hakai Ancient Landscapes Archaeology Project 2011 and 2012 Field Seasons (Permit 2011-171). Report on file in the Provincial Archaeological Report Library, British Columbia Archaeology Branch, Victoria.

2014 Report for the Hakai Ancient Landscapes Archaeology Project 2013 Field Season, (Permit 2011-171). Report on file in the Provincial Archaeological Report Library, British Columbia Archaeology Branch, Victoria.

McMillan Alan D., and Denis E. St. Claire

2005 Ts'ishaa: Archaeology and Ethnography of a Nuu-chah-nulth Origin Site in Barkley Sound. Simon Fraser University Archaeology Press, Burnaby, British Columbia.

Moss, Madonna L.

2012 Understanding Variability in Northwest Coast Faunal Assemblages: Beyond Economic Intensification and Cultural Complexity. Journal of Island and Coastal Archaeology 7:1-22.

Moss, Madonna L., Rick Minor, and Kyla Page-Botelho 2017 Native American Fisheries of the Southern Oregon
Coast: Fine Fraction Needed to Find Forage Fish. Journal of California and Great Basin Anthropology 37:169-182.

Okamoto, Daniel K., Margot Hessing-Lewis, Jameal F. Samhouri, Andrew O. Shelton, Adrian C. Stier, Philip S. Levin, and Anne K. Salomon

2019 Spatial Variation in Exploited Metapopulations Obscures Risk of Collapse. Ecological Applications 30 (3):e02051. DOI:10.1002/eap.2051.

Pomeroy, John Anthony

1972 McNaughton Island Excavation 1972. Unpublished manuscript. Submitted to the Archaeological Branch of British Columbia, Victoria.

1980 Bella Bella Settlement and Subsistence. PhD dissertation, Department of Archaeology, Simon Fraser University, Burnaby, British Columbia.

Quintana Morales, Eréndira M., Dana Lepofsky, and Fikret Berkes

2017 Ethnobiology and Fisheries: Learning from the Past for the Present. Journal of Ethnobiology 37:369-379.

Reimer, Paula, William E. N. Austin, Edouard Bard, Alex Bayliss, Paul G. Blackwell, Christopher Bronk Ramsey, Martin Butzin, et al.

2020 The IntCal20 Northern Hemisphere Radiocarbon Age Calibration Curve (0-55 kcal BP). Radiocarbon 62:725-757.

Stein, Julie K.

1992 Deciphering a Shell Midden. Academic Press, San Diego, California.

Stein, Julie K., Jennie N. Deo, and Laura S. Phillips

2003 Big Sites-Short Time: Accumulation Rates in Archaeological Sites. Journal of Archaeological Science 30: 297-316.

Stuiver, Minze, Paula J. Reimer, and Ron W. Reimer

2021 CALIB 8.2. Electronic document, http://calib.org at accessed 2021-5-1, accessed September 21, 2021.

Sumpter Ian D.

2005 An Analysis of Three Shellfish Assemblages from Ts'ishaa, site DfSi-16 (204T), Benson Island, Pacific Rim National Park Reserve. In Ts'ishaa: Archaeology and Ethnography of a Nuu-chah-nulth Origin Site in Barkley Sound, by Alan D. McMillan and Denis E. St. Claire, pp. 136-172. Simon Fraser University, Archaeology Press, Burnaby, British Columbia.

Taylor, Amanda K., Julie K. Stein, and Stephanie A. E. Jolivette

2011 Big Sites, Small Sites, and Coastal Settlement Patterns in the San Juan Islands, Washington, USA. Journal of Island and Coastal Archaeology 6:287-313.

Walsh, Jessica C., Katrina Connors, Eric Hertz, Laura Kehoe, Tara G. Martin, Brendan Connors, Michael J. Bradford, et al.

2020 Prioritizing Conservation Actions for Pacific Salmon in Canada. Journal of Applied Ecology 57:1688-1699. DOI:10.1111/1365-2664.13646.

Submitted January 6, 2021; Revised January 21, 2021;

Accepted August 24, 2021 